\title{
Differences in Muscle Protein Synthesis and Anabolic Signaling in the Postabsorptive State and in Response to Food in 65-80 Year Old Men and Women
}

\author{
Gordon I. Smith $^{19}$, Philip Atherton ${ }^{29}$, Dennis T. Villareal ${ }^{1}$, Tiffany N. Frimel ${ }^{1}$, Debbie Rankin ${ }^{2}$, Michael J. \\ Rennie $^{2}$, Bettina Mittendorfer ${ }^{*}$.
}

1 School of Medicine, Washington University, St. Louis, Missouri, United States of America, 2 School of Graduate Entry Medicine and Health, University of Nottingham, Derby, United Kingdom

\begin{abstract}
Women have less muscle than men but lose it more slowly during aging. To discover potential underlying mechanism(s) for this we evaluated the muscle protein synthesis process in postabsorptive conditions and during feeding in twenty-nine 6580 year old men $(n=13)$ and women $(n=16)$. We discovered that the basal concentration of phosphorylated eEF2 ${ }^{\text {Thr } 56}$ was $\sim 40 \%$ less $(P<0.05)$ and the basal rate of MPS was $\sim 30 \%$ greater $(P=0.02)$ in women than in men; the basal concentrations of muscle phosphorylated Akt ${ }^{\text {Thr308 }}$, p70s6k ${ }^{\text {Thr389 }}$, elF4E $\mathrm{E}^{\text {Ser209, }}$, and elF4E-BP1 ${ }^{\text {Thr37/46 }}$ were not different between the sexes. Feeding increased $(P<0.05) A^{4} t^{\text {Thr308 }}$ and p70s $66^{\text {Thr } 389}$ phosphorylation to the same extent in men and women but increased $(P<0.05)$ the phosphorylation of elF4E $\mathrm{E}^{\mathrm{Ser} 209}$ and elF4E-BP $1^{\text {Thr37/46 }}$ in men only. Accordingly, feeding increased MPS in men $(P<0.01)$ but not in women. The postabsorptive muscle mRNA concentrations for myoD and myostatin were not different between sexes; feeding doubled myoD mRNA $(P<0.05)$ and halved that of myostatin $(P<0.05)$ in both sexes. Thus, there is sexual dimorphism in MPS and its control in older adults; a greater basal rate of MPS, operating over most of the day may partially explain the slower loss of muscle in older women.
\end{abstract}

Citation: Smith Gl, Atherton P, Villareal DT, Frimel TN, Rankin D, et al. (2008) Differences in Muscle Protein Synthesis and Anabolic Signaling in the Postabsorptive State and in Response to Food in 65-80 Year Old Men and Women. PLoS ONE 3(3): e1875. doi:10.1371/journal.pone.0001875

Editor: Alejandro Lucia, Universidad Europea de Madrid, Spain

Received January 3, 2008; Accepted February 21, 2008; Published March 26, 2008

Copyright: (c) 2008 Smith et al. This is an open-access article distributed under the terms of the Creative Commons Attribution License, which permits unrestricted use, distribution, and reproduction in any medium, provided the original author and source are credited.

Funding: The study was supported by US National Institutes of Health grants AR 49869, AG 025501, RR 00036 (General Clinical Research Center), RR 00954 (Biomedical Mass Spectrometry Resource), and DK 56341 (Clinical Nutrition Research Unit), the University of Nottingham, the UK Biotechnology and Biological Sciences Research Council grants BB/XX510697/1 and BB/C516779/1, and a European Union EXEGENESIS program grant. Philip Atherton is a designated Research Councils UK fellow.

Competing Interests: The authors have declared that no competing interests exist.

*E-mail: mittendb@wustl.edu

9 These authors contributed equally to this work.

\section{Introduction}

Adequate maintenance of muscle mass throughout life is important to preserve locomotor functions and diminish the risk of falling. Furthermore, muscle is the predominant site of body glucose uptake [1-3] and contributes $\sim 25 \%$ to basal energy expenditure, and even more during physical activity [4]. Muscle, therefore, not only serves mechanical functions but also contributes to metabolic and energy homeostasis.

It is common knowledge that healthy adult women have less lean body mass (mostly muscle) and more fat than men $[5,6]$. However, the age-associated decrease in lean body mass and muscle mass is slower in women than in men [5,7-9]. Unfortunately, little is known about the mechanisms that lead to sexual dimorphism in body composition. It is thought that most of it is due to differences in the sex-hormone milieu in men and women. It has been repeatedly demonstrated in vitro [10,11], in vivo in animal models [10,12-14], and in human subjects $[15,16]$ that testosterone stimulates skeletal muscle protein synthesis (MPS) and increases muscle mass. There is also evidence that ovarian hormones inhibit MPS [17] and muscle growth [18,19] in rats. Nevertheless, several investigators who have measured the rates of MPS in men and women have found no differences [20-22].
The fact that no sex differences in MPS have been reported in the literature might be because these studies were conducted in young and middle-age adults with a constant muscle mass during postabsorptive conditions, when sex differences may be small or non-existent. We reasoned that sex differences in muscle protein turnover would become apparent at life stages when muscle mass is changing (e.g., during growth in adolescence or wasting during aging) and/or during acute anabolic or catabolic challenges (e.g., feeding or injury). Accordingly, we hypothesized that such differences might be revealed by a comparison of rates of MPS in older men and women during basal, postabsorptive conditions and feeding. We, therefore, measured the fractional rate of MPS during basal, postabsorptive conditions and during feeding by using stable-isotope labeled amino acid tracer techniques in 6580 year old men and women; we also measured the concentrations of total muscle RNA and protein to gain insight into the protein synthetic capacity and translational efficiency of the muscle $[23,24]$. Furthermore, we measured the activation (as phosphorylation) of elements of intracellular signaling pathways involved in the regulation of MPS (Akt; ribosomal protein S6 protein kinase [p70s6k]; eukaryotic initiation factor 4E [eIF-4E]; eIF4E binding protein 1 [eIF4E-BP1]; and eukaryotic elongation factor 2 [eEF2]) $[25,26]$ and the mRNA expression of proteins involved in the 
regulation of muscle mass (i.e., the muscle growth inhibitor myostatin $[27,28]$ and the muscle growth factor myoD [29]). We also measured plasma C-reactive protein (CRP) concentration as an index of inflammation because the concentrations of CRP and pro-inflammatory cytokines in blood have been found to be negatively associated with rates of MPS [30] and may contribute to skeletal muscle atrophy and reduced functional capacity, especially during aging [31-33].

\section{Methods}

\section{Subjects}

We studied 13 men and 16 women, aged 65 to $80 \mathrm{y}$; men and women were matched for age and body mass index (Table 1). All subjects were considered to be in good health after completing a comprehensive medical evaluation. None of the subjects engaged in regular exercise, reported excessive alcohol intake, smoked, or received hormone replacement therapy. Ten women and six men were treated for hypertension, and four women and four men were treated for hypercholesteremia; the drug regimen had been initiated several years before subjects entered the study and had been stable for several months before beginning the study. Written, informed consent was obtained from all subjects before their participation in the study, which was approved by the Human Studies Committee and the General Clinical Research Center (GCRC) Advisory Committee at Washington University School of Medicine in St. Louis, MO.

\section{Experimental protocol}

Approximately two weeks before the protein metabolism study, subjects' total body fat-free mass (FFM) and appendicular muscle mass [31] were measured by using dual-energy X-ray absorptiometry (Delphi-W densitometer, Hologic, Waltham, MA). Magnetic resonance imaging (MRI) was used to quantify thigh muscle volume; images were acquired with a 1.5-T superconducting magnet (Siemens, Iselin, NJ) and a T1-weighted pulse sequence. Eight 8-mm-thick axial images, starting $10 \mathrm{~cm}$ proximal to the distal edge of the femur, with a 7-mm intersection gap, were acquired and muscle volume in each of the images was determined with the NIH Image Analysis Software (Analyze Direct software (version 7.0; Mayo Clinic, Rochester, MN), which utilizes pixel brightness to distinguish muscle from other tissues. Thigh muscle volume in the region of interest was calculated as the sum of the individual muscle volumes and the sum of the muscle volumes in

Table 1. Subject characteristics

\begin{tabular}{|c|c|c|c|}
\hline & Men & Women & P-value \\
\hline Age (years) & $71 \pm 2$ & $69 \pm 1$ & 0.16 \\
\hline Body mass index $\left(\mathrm{kg} \cdot \mathrm{m}^{-2}\right)$ & $36 \pm 1$ & $38 \pm 2$ & 0.34 \\
\hline Body mass $(\mathrm{kg})^{\mathrm{a}}$ & $108 \pm 3$ & $98 \pm 4$ & 0.09 \\
\hline Fat free mass $(\mathrm{kg})^{a}$ & $67 \pm 2$ & $51 \pm 2$ & $<0.001$ \\
\hline Fat free mass ( $\%$ body weight) & $62 \pm 1$ & $52 \pm 1$ & $<0.001$ \\
\hline Appendicular muscle mass $(\mathrm{kg})^{\mathrm{a}}$ & $29 \pm 1$ & $22 \pm 1$ & $<0.001$ \\
\hline Appendicular muscle mass (\% FFM) & $43 \pm 1$ & $43 \pm 1$ & 0.40 \\
\hline Thigh muscle volume $\left(\mathrm{cm}^{3}\right)^{\mathrm{b}}$ & $2477 \pm 113$ & $1963 \pm 93$ & 0.002 \\
\hline $\begin{array}{l}\text { Values are means } \pm \text { SEM. } \\
\text { a Measured by DEXA as described in } t \\
{ }^{b} \text { Measured by MRI as described in th } \\
\text { doi: } 10.1371 \text { journal.pone. } 0001875 . t 00\end{array}$ & $\begin{array}{l}\text { Experimer } \\
\text { Experiment }\end{array}$ & $\begin{array}{l}\text { protocol se } \\
\text { rotocol sec }\end{array}$ & \\
\hline
\end{tabular}

the intersection gap, which were assumed to be the same as in the preceding image.

Three days before the protein metabolism study, subjects were instructed to adhere to their usual diet and to refrain from vigorous exercise until completion of the study. The evening before the study, subjects were admitted to the GCRC. At $2000 \mathrm{~h}$, they consumed a standard meal which provided $50.2 \mathrm{~kJ}$ per $\mathrm{kg}$ body weight; $15 \%$ of the meal energy was provided as protein, $55 \%$ as carbohydrates and $30 \%$ as fat. Subjects then rested in bed and fasted (except for water) until completion of the study the next day. At $\sim 0600 \mathrm{~h}$ on the following morning, a cannula was inserted into an antecubital vein for the infusion of a stable isotope labeled leucine tracer; another cannula was inserted into a vein of the contralateral hand for blood sampling. At $\sim 0800 \mathrm{~h}$, a blood sample and a muscle biopsy from the quadriceps femoris were obtained to determine the background leucine enrichment in plasma, the concentrations of testosterone, progesterone, 17Bestradiol, sex hormone binding globulin (SHBG), and CRP in plasma, the background leucine enrichment in muscle tissue fluid and muscle protein, and the concentration of total RNA and protein in muscle. Muscle tissue $(\sim 50-100 \mathrm{mg})$ was obtained under local anesthesia (lidocaine, $2 \%$ ) by using Tilley-Henkel forceps [34]. Immediately afterwards, a primed, constant infusion of $\left[5,5,5-{ }^{2} \mathrm{H}_{3}\right]$ L-leucine (98 Atoms \% purchased from Cambridge Isotope Laboratories Inc, Andover, MA; priming dose: $4.8 \mu \mathrm{mol} \mathrm{kg}$ body $\mathrm{wt}^{-1}$, infusion rate: $0.08 \mu \mathrm{mol} \mathrm{kg}$ body $\mathrm{wt}^{-1} \cdot \mathrm{min}^{-1}$ ) was started and maintained until completion of the study $\sim 6 \mathrm{~h}$ later. At $210 \mathrm{~min}$ after the start of the leucine tracer infusion, a second muscle biopsy was obtained to determine the basal rate of MPS (as incorporation of $\left[5,5,5-{ }^{2} \mathrm{H}_{3}\right]$ leucine into muscle protein; see Calculations) and the basal concentrations of phosphorylated elements of intramuscular signal transduction proteins (Akt; p70s6k; eIF-4E; eIF4E-BP1; and eEF2) involved in the regulation of MPS. Immediately after the second biopsy, a liquid meal (Ensure ${ }^{\circledR}$, Abbott Laboratories, Abbott Park, IL, USA, containing $15 \%$ of energy as protein, $55 \%$ as carbohydrate and $30 \%$ as fat) was given intermittently in small boluses every 10 minutes for $150 \mathrm{~min}$ so that every subject received a priming dose of $23 \mathrm{mg}$ protein $\cdot \mathrm{kg} \mathrm{FFM}^{-1}$ and $70 \mathrm{mg}$ protein $\cdot \mathrm{kg}$ $\mathrm{FFM}^{-1} \cdot \mathrm{h}^{-1}$ during the $2.5 \mathrm{~h}$ feeding period. At the onset of feeding, the infusion rate of labeled leucine was increased to $0.12 \mu \mathrm{mol} \mathrm{kg}$ body $\mathrm{wt}^{-1} \cdot \mathrm{min}^{-1}$ to adjust for the increased plasma leucine availability. A third muscle biopsy was obtained at $360 \mathrm{~min}$ (i.e., $150 \mathrm{~min}$ after the first food aliquot) to determine both MPS and the intracellular signaling responses to feeding. The second and third biopsies were obtained from the leg contralateral to that biopsied initially through the same incision, but with the forceps directed in proximal and distal direction so that the two biopsies were collected $\sim 5-10 \mathrm{~cm}$ apart. Blood samples were obtained every $30 \mathrm{~min}$ during the entire study period to determine plasma leucine enrichment and concentration, and concentrations of glucose, and insulin. The tracer infusions were stopped and cannulae were removed after the last (third) biopsy and the final blood draw were completed.

\section{Sample collection and storage}

Approximately $4 \mathrm{ml}$ of blood was collected on each occasion. One milliliter was collected in pre-chilled tubes containing heparin, plasma separated immediately by centrifugation and glucose concentration measured immediately. The remaining blood $(\sim 3 \mathrm{ml})$ was collected in pre-chilled tubes containing EDTA, plasma was separated by centrifugation within $30 \mathrm{~min}$ of collection and then stored at $-80^{\circ} \mathrm{C}$ until final analysis. Muscle samples were rinsed in ice-cold saline immediately after collection, 
cleared of visible fat and connective tissue, frozen in liquid nitrogen and stored at $-80^{\circ} \mathrm{C}$ until final analysis.

\section{Sample processing and analyses}

Plasma glucose concentration was determined on an automated glucose analyzer (Yellow Spring Instruments, Yellow Springs, $\mathrm{OH})$. Plasma insulin concentration was determined by radioimmunoassay (Linco Research, St. Louis, MO). ELISA was used to determine plasma concentrations of testosterone, progesterone, 17ß-estradiol, SHBG (all Immuno-Biological Laboratories, IBLAmerica, Minneapolis, MN), and CRP (ALPCO Diagnostics, Salem, NH).

To determine plasma leucine concentration and labeling of plasma leucine and $\alpha$-ketoisocaproate (KIC), a known amount of norleucine was added to the plasma, proteins were precipitated, and the supernatant, containing free amino acids and their ketoanalogues, was collected to prepare the $t$-butyldimethylsilyl $(t-$ BDMS) and trimethylsilyl derivative of leucine and KIC, respectively, to determine their tracer-to-tracee ratios (TTR) by gas-chromatography/mass-spectrometry (GC-MS; MSD 5973 System, Hewlett-Packard) [35].

To determine leucine labeling of muscle proteins and tissue fluid, samples $(\sim 20 \mathrm{mg})$ were homogenized in $1 \mathrm{ml}$ trichloroacetic acid solution $(3 \% \mathrm{w} / \mathrm{v})$, proteins precipitated by centrifugation, and the supernatant, containing free amino acids, collected. The pellet containing muscle proteins was washed and then hydrolyzed in $6 \mathrm{~N} \mathrm{HCl}$ at $110{ }^{\circ} \mathrm{C}$ for $24 \mathrm{~h}$. Amino acids in the protein hydrolysate and supernatant samples were purified on cationexchange columns (Dowex 50W-X8-200, Bio-Rad Laboratories, Richmond, CA), and the t-BDMS derivative of leucine prepared to determine its TTR by GC-MS (MSD 5973 System, HewlettPackard) analysis [35]. The extent of leucine labeling in plasma, muscle tissue fluid, and muscle protein were calculated based on the simultaneously measured TTR of standards of known isotope labeling.

Western analysis was used to measure the phosphorylation of Akt, p70s6k, eIF-4E, eIF4E-BP1, and eEF2. Briefly, frozen muscle tissue $(\sim 20 \mathrm{mg})$ was rapidly homogenized with scissors in ice-cold buffer (50 mM Tris-HCL pH 7.5, 1 mM EDTA, 1 mM EGTA, $10 \mathrm{mM}$ glycerophosphate, $50 \mathrm{mM} \mathrm{NaF}, 0.1 \%$ Triton-X, $0.1 \% 2-$ mercaptoethanol, 1 complete protease inhibitor tablet [Roche Diagnostics Ltd, Burgess Hill, UK]) at $10 \mu \mathrm{l} \cdot \mathrm{mg}^{-1}$ tissue. Proteins were extracted by shaking for $15 \mathrm{~min}$ at $4^{\circ} \mathrm{C}$ and samples were then centrifuged at $13000 \times g$ for $10 \mathrm{~min}$ at $4^{\circ} \mathrm{C}$ and the supernatant, containing the proteins was collected. The protein concentration in the supernatant was determined by the Bradford method with a commercial reagent (B6916, Sigma-Aldrich, St. Louis, MO) and adjusted to $3 \mathrm{mg} \mathrm{ml}^{-1}$ in $3 \times$ Laemmli buffer. Fifty micrograms of protein from each sample were loaded onto $12 \%$ XT-Bis Tris gels, separated by SDS PAGE, and transferred on ice at $100 \mathrm{~V}$ for $45 \mathrm{~min}$ to methanol pre-wetted $0.2 \mu \mathrm{m}$ PVDF membranes. Blots were then incubated sequentially with $5 \%(\mathrm{w} / \mathrm{v})$ non-fat milk for $1 \mathrm{~h}$, primary antibodies overnight at $4^{\circ} \mathrm{C}$, and then secondary antibody (1:2000 anti-rabbit; New England Biolabs, Ipswich, MA) for $1 \mathrm{~h}$. The following primary antibodies were used at a concentration of 1:1000: $\mathrm{Akt}^{\text {Thr308 }}$, p70s6k $\mathrm{k}^{\text {Thr389; }}$ $4 \mathrm{E}-\mathrm{BP} 1^{\text {Thr37/46 }}, \mathrm{eEF} 2^{\text {Thr56 }}$, and GADPH (loading control), purchased from New England Biolabs, and eIF4E ${ }^{\text {Ser209 }}$ purchased from Santa Cruz Biotechnology Inc. (Santa Cruz, CA). Membranes were developed using Immunstar (Bio-Rad Laboratories, Richmond, CA) and the protein bands were visualized and quantified by densitometry on a Chemidoc XRS (Bio-Rad Laboratories, Inc. Hercules, CA) ensuring no pixel saturation. Data were expressed in relation to GADPH.
The expression of genes involved in the regulation of muscle mass was evaluated by real-time, reverse transcription polymerase chain reaction (RT-PCR). Frozen tissue samples (5-10 mg) were homogenized in TRIZOL ${ }^{\circledR}$ using a Polytron for $15 \mathrm{~s}$ on ice. Total RNA was extracted according to the instructions provided by the manufacturer (Sigma-Aldrich, St. Louis, MO) and quantified by spectrophotometry at $260 \mathrm{~nm}$. An aliquot $(0.5 \mu \mathrm{g})$ was loaded onto a $1 \%$ agarose gel to check RNA quality and loading by visualization of $28 \mathrm{~s}$ and $18 \mathrm{~s}$ rRNA. Reverse transcription was performed using the iScript synthesis kit (Bio-Rad Laboratories, Richmond, CA) with $1 \mu \mathrm{g}$ of total RNA in a reaction volume of $20 \mu \mathrm{l}(4 \mu \mathrm{l}$ iScript reaction mix, $1 \mu \mathrm{l}$ iScript reverse transcriptase, $1 \mu \mathrm{l}$ RNA template, $14 \mu \mathrm{l}$ RNase-free water). The final RT products were adjusted to $100 \mu \mathrm{l}$ each using RNase free water. The following primers were used for myostatin and myoD (all $5^{\prime}$ to $\left.3^{\prime}\right)$. Myostatin forward: CTA CAA CGG AAA CAA TCA TTA CCA, reverse: GTT TCA GAG ATG GGA TTC CAG TAT; MyoD forward: CGG CCT GAG CAA AGT AAA TG, reverse: GCG CTC GAT ATA GCG GAT G. Sybr Green ${ }^{\circledR}$ PGR analyses were carried out on the iQ5 Real-Time PGR Detection System (Bio-Rad Laboratories, Richmond, CA) using the following cycle conditions: $3 \mathrm{~min}$ at $95^{\circ} \mathrm{C}$, followed by 40 cycles of $1 \mathrm{~min}$ at $60^{\circ} \mathrm{C}$, and $15 \mathrm{~s}$ at $95^{\circ} \mathrm{C}$. For each gene, real time RT-PCR was conducted in duplicate in $25 \mu \mathrm{l}$ reaction volumes containing $12.5 \mu \mathrm{l}$ qPCR SuperMix (Bio-Rad Laboratories, Richmond, CA), $0.75 \mu \mathrm{l}$ of each primer $\left(10 \mathrm{pmol} \mu^{-1}\right), 9 \mu \mathrm{l}$ RAse-free water and $2 \mu \mathrm{l}$ of 1:5 diluted cDNA. PCR products were checked for amplicon specificity by both melting curve and agarose gel electrophoresis. Results were analyzed using the $2-\Delta \Delta \mathrm{Ct}$ method with 28s as internal control [36]. Due to lack of sufficient muscle tissue, these analyses were carried out in only 7 of the 13 men and 7 of the 16 women.

To determine the total RNA to protein ratio in muscle, an index of the capacity for protein synthesis, an aliquot of the total RNA preparation prepared for RT-PCR was sequentially extracted (RNA $>$ DNA $>$ protein) according to the manufacturers (SigmaAldrich, St. Louis, MO) protocol. Total RNA was quantified after complete removal of the upper phase following phase separation; protein concentration was quantified after removal of the DNA interphase and precipitation of proteins with acetone from the bottom layer, which were then washed and resuspended in 1\% SDS. Total RNA was quantified (in $\mu \mathrm{g}$ per $\mathrm{g}$ wt weight) spectrophotometrically at $260 \mathrm{~nm}$ and protein was quantified (in $\mathrm{mg}$ per $\mathrm{g}$ wt weight) at $595 \mathrm{~nm}$ using Bradford reagents at a 1:10 dilution to reduce SDS interference. Due to lack of sufficient muscle tissue, these analyses were carried out in only 9 of the 13 men and 7 of the 16 women.

\section{Calculations}

Leucine rate of appearance $(\mathrm{Ra})$ in plasma was calculated by dividing the rate of $\left[5,5,5-{ }^{2} \mathrm{H}_{3}\right]$ leucine infusion by the steady state plasma KIC TTR during basal, postabsorptive conditions and feeding. Leucine Ra during basal conditions is an index of the rate of whole-body proteolysis; during feeding, leucine Ra represents the sum of the rate of leucine release into plasma from proteolysis plus the rate of transfer of absorbed leucine from the meal into the systemic circulation.

The fractional synthesis rate (FSR) of mixed muscle protein was calculated from the rate of incorporation of $\left[5,5,5-{ }^{2} \mathrm{H}_{3}\right]$ leucine into muscle protein, using a standard precursor-product model as follows: $\mathrm{FSR}=\Delta \mathrm{E}_{\mathrm{p}} / \mathrm{E}_{\mathrm{ic}} \times 1 / t \times 100$; where $\Delta \mathrm{E}_{\mathrm{p}}$ is the change between two consecutive biopsies in extent of labeling (TTR) of protein-bound leucine. $\mathrm{E}_{\mathrm{ic}}$ is the mean labeling over time of the precursor for protein synthesis and $t$ is the time between biopsies. The free leucine labeling in muscle tissue fluid was chosen to 
represent the immediate precursor for MPS (i.e., aminoacyl-tRNA) [37]. Values for FSR are expressed as $\% \cdot h^{-1}$. The absolute rate of muscle protein synthesis ( $\mathrm{g}$ protein per hour) was calculated by multiplying the FSR by the total appendicular muscle protein mass, which was assumed to be $20 \%$ of total appendicular muscle mass. We have recently found that differences in the rates of muscle protein synthesis in different muscles are negligible[38]; thus, it is reasonable to extrapolate our data obtained in the vastus lateralis to all skeletal muscles in the body.

The translation efficiency ( $\mathrm{mg}$ protein produced per $\mu \mathrm{g}$ RNA per hour) was calculated by dividing the product of the muscle protein FSR (in $\% \cdot \mathrm{h}^{-1}$ ) and the muscle protein concentration (in mg per $\mathrm{g}$ wet tissue) by the muscle total RNA concentration (in $\mu \mathrm{g}$ per $g$ wet tissue) $[23,24]$.

\section{Statistical analysis}

All data sets were tested for normality. Differences between men and women in subject characteristics and single time-point measurements (e.g., plasma sex hormone and CRP concentrations) were evaluated by using Student's t-test for normally distributed data and the Mann-Whitney $U$ test for data which were not normally distributed (i.e., plasma SHBG, testosterone, progesterone, 17ßestradiol and CRP concentrations). Analysis of variance (ANOVA) was used to evaluate possible differences between men and women in plasma glucose, insulin, and leucine concentrations, muscle protein FSR, muscle intracellular signaling elements, and muscle mRNA expression during postabsorptive and fed conditions. If necessary, data were $\log$ transformed to achieve normally distributed data sets before analysis. A $P$ value of $\leq 0.05$ was considered statistically significant. Data in the text are presented as mean \pm SEM or median with $25^{\text {th }}$ and $75^{\text {th }}$ percentiles in brackets for skewed data sets; data in tables and figures are presented as indicated in the legends.

\section{Results}

\section{Subjects' age and body-composition}

Men and women were matched for age and BMI (Table 1). Total body FFM, total muscle mass and leg muscle volume were $225 \%$ less in women than in men; however, the relative contribution of muscle mass to total body FFM was not different in men and women (Table 1).

\section{Plasma sex hormone and CRP concentrations}

Plasma SHBG concentration was not different between men and women (Table 2). Plasma testosterone concentration was 10 times greater $(P<0.001)$ in men than in women whereas plasma progesterone and 17ß-estradiol concentrations were not different between the sexes (Table 2). Plasma CRP concentration was not different between men and women (Table 2).

Table 2. Plasma sex hormone and CRP concentrations.

\begin{tabular}{lll}
\hline & & \\
\hline & Men & Women \\
\hline SHBG $\left(\mathrm{nmol} \mathrm{I}{ }^{-1}\right)$ & $23.1(20.1,26.0)$ & $25.9(19.2,44.8)$ \\
Testosterone $\left(\mathrm{nmol} \mathrm{I}^{-1}\right)$ & $12.2(8.8,18.1)$ & $1.1(0.9,1.7)^{*}$ \\
Progesterone $\left(\mathrm{ng} \mathrm{ml}^{-1}\right)$ & $0.12(0.05,0.31)$ & $0.04(0.02,0.12)$ \\
17ß-Estradiol $\left(\mathrm{pg} \mathrm{ml}^{-1}\right)$ & $11.3(10.8,30.9)$ & $10.9(10.0,11.9)$ \\
CRP $\left(\mathrm{mg} \mathrm{I}^{-1}\right)$ & $3.08(2.43,4.23)$ & $2.80(0.98,3.60)$ \\
\hline
\end{tabular}

Values are median with quartiles in parentheses.

*Value significantly different from corresponding value in men $(P<0.001)$ doi:10.1371/journal.pone.0001875.t002

\section{Plasma glucose, insulin, and leucine concentrations}

Basal plasma glucose and insulin concentrations were not different between men and women (Table 3). Feeding increased plasma glucose concentration by $\sim 25 \%(P<0.001)$ and plasma insulin concentration by $\sim 200 \%(P<0.001)$ with no differences between the sexes (Table 3). Basal plasma leucine concentration was $\sim 15 \%$ less in women than in men (Table 3), and feeding increased plasma leucine concentration by $\sim 15 \%(P<0.001)$ in both sexes (Table 3).

\section{Whole-body leucine Ra}

Rates of leucine Ra during basal, postabsorptive conditions (an index of whole-body protein breakdown) and total leucine $\mathrm{Ra}$ during feeding were not different in men (2.24 \pm 0.08 and $2.56 \pm 0.08 \mu \mathrm{mol} \mathrm{kg}{ }^{-1} \mathrm{FFM} \cdot \mathrm{min}^{-1}$, respectively) and women (2.20 \pm 0.09 and $2.62 \pm 0.09 \mu \mathrm{mol} \mathrm{kg}{ }^{-1} \mathrm{FFM} \cdot \mathrm{min}^{-1}$, respectively).

\section{Muscle protein synthesis}

The capacity for MPS (i.e., total RNA-to-protein ratio in muscle) tended to be greater (by $\sim 20 \% ; P=0.18$ ) in women than in men (5.8 \pm 0.6 vs. $4.7 \pm 0.5 \mu \mathrm{g}$ RNA $\cdot \mathrm{mg}$ protein $^{-1}$, respectively).

Mixed muscle protein FSR during basal, postabsorptive conditions was $\sim 30 \%$ greater $(P=0.02)$ in women than in men (Figure 1). Feeding had no effect on the FSR in women but increased $(P<0.01)$ it in men to values similar to those in women (Figure 1). The absolute rate of muscle protein synthesis, adjusted for differences in total muscle mass between the sexes, was 116 [104, 143] $\mathrm{mg}$ of muscle protein per hour per $\mathrm{kg}$ of appendicular skeletal muscle mass in women and 90 [78, 115] $\mathrm{mg}$ of muscle protein per hour per $\mathrm{kg}$ of appendicular skeletal muscle mass in men $(\mathrm{P}=0.02)$; it increased by $35[13,79] \mathrm{mg}$ per hour per $\mathrm{kg}$ of appendicular skeletal muscle mass in response to the meal in men $(P<0.01)$, but did not change significantly from basal values (by 11 $[-10,41] \mathrm{mg}$ of muscle protein per hour per $\mathrm{kg}$ of appendicular skeletal muscle mass) in women.

The rate of MPS in relation to muscle RNA concentration, a measure of the translational efficiency in muscle, was not different between men and women during basal, postabsorptive conditions $\left(0.012 \pm 0.003\right.$ vs. $0.013 \pm 0.002 \mathrm{mg}$ protein $\left.\mu \mathrm{g} \mathrm{RNA}^{-1} \cdot \mathrm{h}^{-1}\right)$ and increased with feeding in men (to $0.019 \pm 0.006 \mathrm{mg}$ protein $\mu \mathrm{g}$ $\mathrm{RNA}^{-1} \cdot \mathrm{h}^{-1} ; \quad P=0.058$ vs basal) but not in women (to $0.015 \pm 0.001 \mathrm{mg}$ protein $\left.\cdot \mu \mathrm{g} \mathrm{RNA}^{-1} \cdot \mathrm{h}^{-1}\right)$.

\section{Phosphorylation of signaling transduction proteins in muscle}

In the postabsorptive state, the extent of phosphorylation of $\mathrm{Akt}^{\text {Thr308 }}, \mathrm{p} 70 \mathrm{~s}^{\mathrm{Th}} \mathrm{k}^{\text {Thr389 }}$, eIF4E $\mathrm{E}^{\text {Ser209 }}$ and eIF4E-BP1 ${ }^{\text {Thr37/46 }}$ in muscle was not different in men and women (Figure 2). The

Table 3. Plasma glucose, insulin, and leucine concentrations.

\begin{tabular}{llllll}
\hline & & & & \\
& Men & & \multicolumn{2}{l}{ Women } & \\
\cline { 2 - 3 } \cline { 5 - 6 } & Fasted & Fed & & Fasted & Fed \\
\hline Glucose $\left(\mathrm{mmol} \mathrm{I}^{-1}\right)$ & $5.2 \pm 0.1$ & $6.5 \pm 0.2^{\dagger}$ & $5.4 \pm 0.2$ & $6.9 \pm 0.1^{\dagger}$ \\
Insulin $\left(\mu \mathrm{ml}^{-1}\right)$ & $15.5 \pm 2.2$ & $47.8 \pm 7.3^{\dagger}$ & & $14.4 \pm 3.1$ & $41.5 \pm 5.6^{\dagger}$ \\
Leucine $\left(\mu \mathrm{mol} \mathrm{I}^{-1}\right)$ & $133 \pm 4$ & $144 \pm 4^{\dagger}$ & $111 \pm 6^{*}$ & $126 \pm 6^{* \dagger}$ \\
\hline
\end{tabular}

Values are mean \pm SEM.

*Value significantly different from corresponding value in men $(P=0.011)$; †value significantly different from corresponding value during basal, postabsorptive (fasted) conditions $(P<0.001)$

doi:10.1371/journal.pone.0001875.t003 

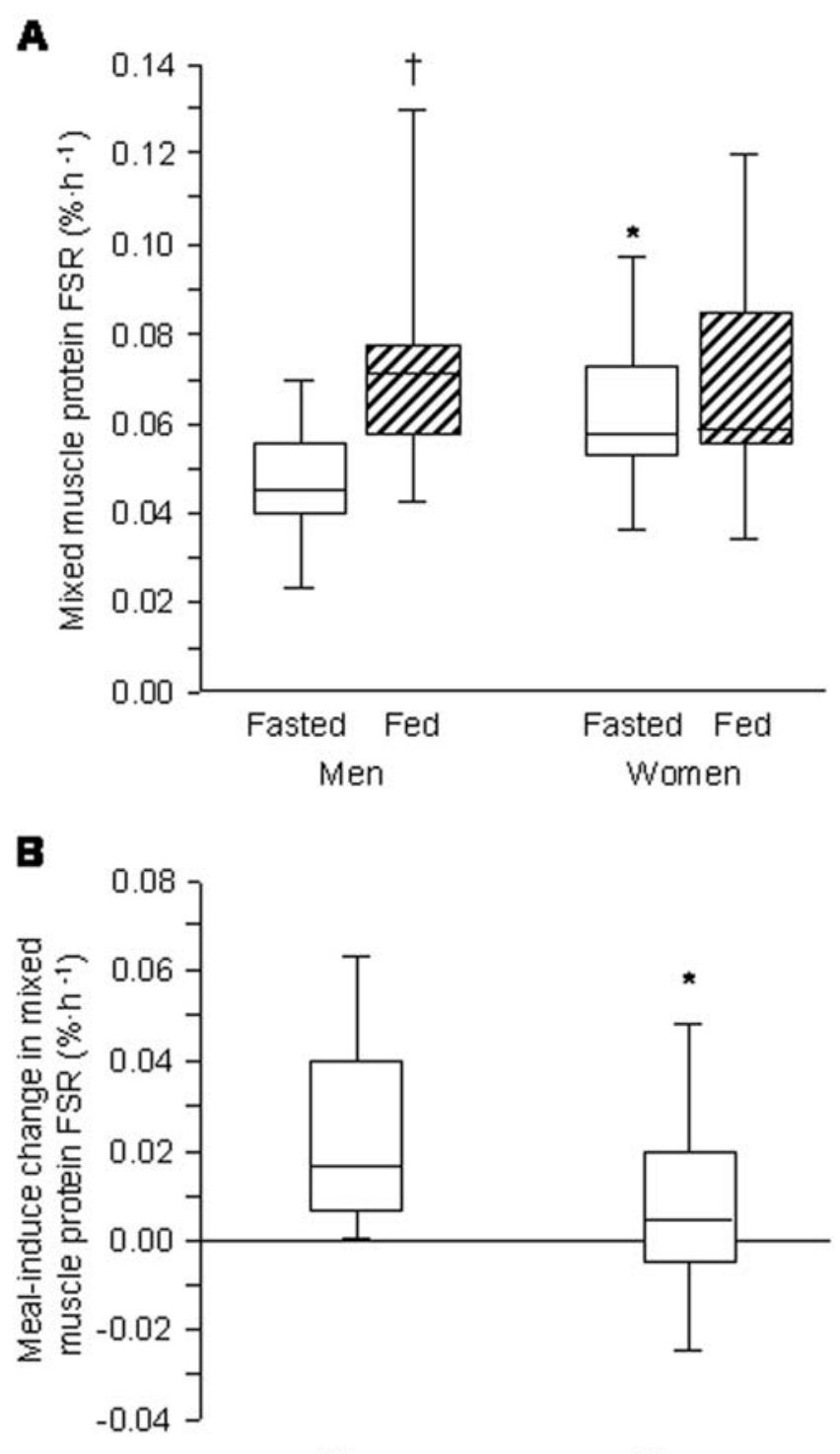

Men Women

Figure 1. Muscle protein synthesis rate in men and women. Panels $A$ and $B$ show the mixed skeletal muscle protein fractional synthesis rate (FSR) during basal, post-absorptive conditions (fasted) and liquid mixed meal consumption (fed) in men and women $(\mathbf{A})$ and the meal-induced change in the FSR in men and women (B). Graphs show the median (central horizontal line), $25^{\text {th }}$ and $75^{\text {th }}$ percentiles (box), and minimum and maximum values (vertical lines). ${ }^{*}$ Value significantly different from corresponding value in men. ${ }^{\dagger}$ Value significantly different from corresponding value during basal, postabsorptive (fasted) conditions.

doi:10.1371/journal.pone.0001875.g001

feeding-induced increases in the phosphorylation of $\mathrm{Akt}^{\text {Thr308, }}$ p70s6k ${ }^{\text {Thr389 }}$ (both $P<0.01$ ) were also not different in the two sexes (Figure 2). In contrast, feeding increased $(\mathrm{P}<0.01)$ the phosphorylation of eIF4E $\mathrm{E}^{\text {Ser209 }}$ and eIF4E-BP1 ${ }^{\text {Thr37/46 }}$ in men but had no effect on their phosphorylation in women (Figure 2). Phosphorylated eEF2 $2^{\text {Thr56 }}$ in muscle was $\sim 40 \%$ less $(P<0.05)$ in women than in men both during postabsorptive conditions and feeding (Figure 2); there was a tendency for a decrease in the phosphorylation of $\mathrm{eEF}^{\mathrm{Thr} 56}$ in both sexes with feeding (Figure 2) but this difference did not reach statistical significance $(P=0.103)$.
mRNA expression of proteins involved in the regulation of muscle mass

The mRNA concentrations of myostatin and myoD during postabsorptive conditions were not different in men and women (Figure 3). Feeding decreased the concentration of myostatin mRNA $(P<0.05)$ and increased the concentration of myoD mRNA $(P<0.05)$ to the same extent in the two sexes (Figure 3$)$.

\section{Discussion}

In this study we uncovered marked sexual dimorphism between older men and women in a variety of aspects of muscle protein metabolism. The differences we observed between older men and women, namely a $\sim 30 \%$ greater basal rate of mixed MPS in women than in men and resistance of MPS to feeding a liquid mixed meal (providing a total of $\sim 10 \mathrm{~g}$ of protein) in women, are consistent with a recent study in which comprehensive oligonucleotide microarrays were used to discover potential differences between men and women in the expression of genes involved in the regulation of muscle mass [39]; in this study it was found that women had a two-fold greater expression of two genes that encode proteins with inhibitory properties on growth factor pathways in muscle. On the other hand, the results from our study are in clear contrast to the results from previous workers who searched for potential sex differences in human muscle protein metabolism and found none [20-22]. However, those earlier studies were conducted in young adults (average age: 23-27 y) and we hypothesized that sex differences in human muscle protein turnover would only become apparent at life stages when muscle mass was changing (e.g., during adolescent growth or wasting during aging) and/or possibly during acute anabolic or catabolic challenges (e.g., with feeding or injury). To our knowledge the current work is the first to demonstrate in human beings sex differences in the rate of MPS and provides some insight concerning the control of MPS and the different rates of muscle loss with aging between men and women.

The greater basal rate of mixed MPS in older women was probably mediated by a combination of a greater capacity for protein synthesis combined with a relatively more active translational process at the elongation stage of protein synthesis because first, there was the trend for a $\sim 20 \%$ greater muscle RNA-to-protein ratio in women than in men, indicating a greater capacity for MPS [24] in them and secondly, muscle of older women had a $40 \%$ smaller degree of phosphorylation of $\mathrm{eEF}^{\text {Thr56 }}$, a molecule regulating elongation of nascent protein chains which is deactivated by phosphorylation [25]. We found no differences between sexes in the extent of phosphorylation for components of the $\mathrm{PKB} / \mathrm{mTOR} / \mathrm{p} 70 \mathrm{~s} 6 \mathrm{k}$ signaling pathway, or the phosphorylation of elements involved in the regulation of translation initiation (eIF4E and eIF4e-BPl) at baseline (fasted). Furthermore, the expression in muscle of mRNA for myostatin and myoD, cell regulatory proteins affecting muscle size [26-29], was not different between the sexes, which makes it unlikely that they are involved in regulating the basal rate of MPS, although, we cannot from our data rule out differences in the muscle myostatin and myoD protein concentration (and thus in cell function). Indeed, a greater myostatin protein concentration has been found in female than male mice [40], which is consistent with the observed sexual dimorphism in muscle mass but not with our results of a lower basal rate of MPS in older men, assuming extrapolation between species is valid. Plasma glucose, insulin, and CRP concentrations were not different in men and women, so these results also provide no explanation of baseline sex differences in MPS. 
A
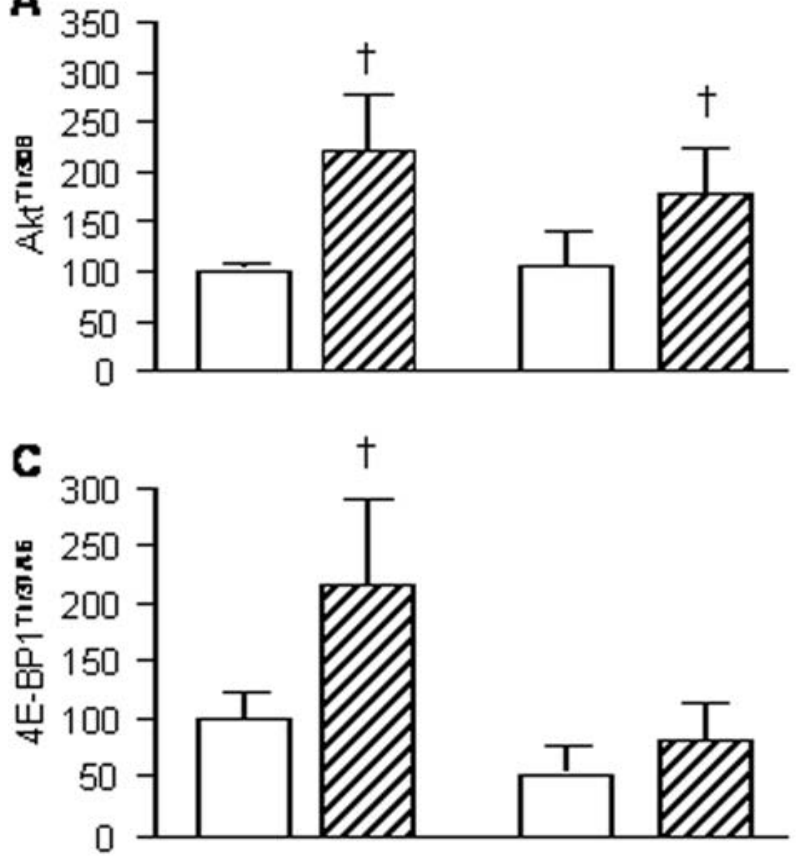

E

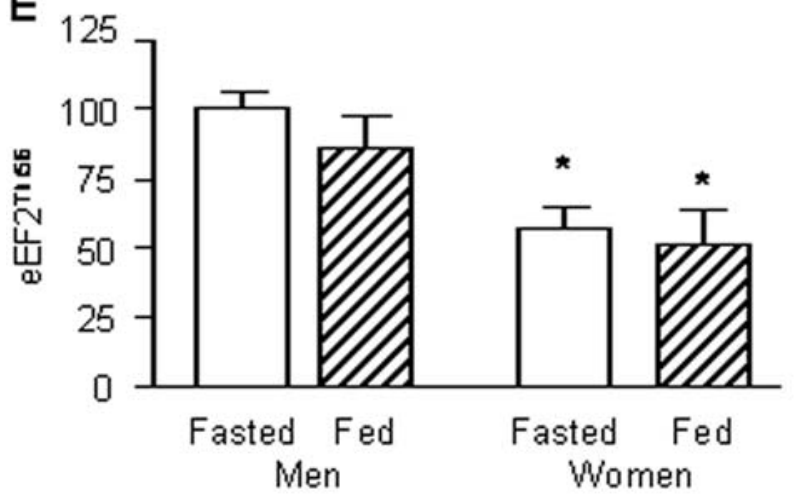

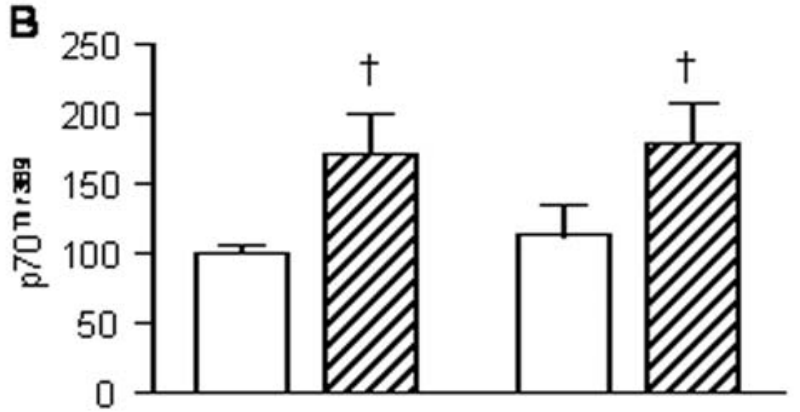

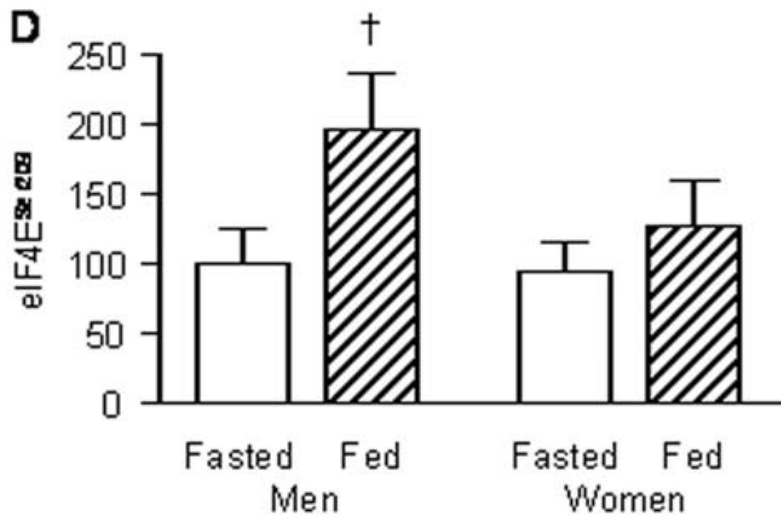

Figure 2. Phosphorylation of anabolic signaling transduction molecules in muscle of men and women. Panels $A-E$ show concentrations

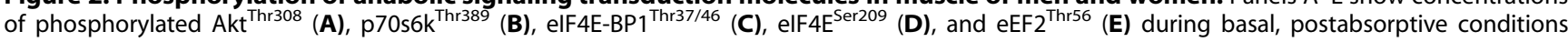
(fasted) and liquid mixed meal consumption (fed) in men and women. Values are means \pm SEM. * Value significantly different from corresponding value in men; ${ }^{\dagger}$ Value significantly different from corresponding value during basal, postabsorptive (fasted) conditions.

doi:10.1371/journal.pone.0001875.g002

The proximal, underlying, biological reasons that the sexual dimorphism in muscle protein metabolism and its control is apparently of late onset (aging, as in the present study, vs. young and middle-age adulthood [20-22]) are not clear but are most probably related to the changes with advancing age in the sex hormone milieu. This may at first seem counterintuitive, because men had a ten-fold excess of testosterone compared with women, with a concomitant relatively small or no difference in plasma progesterone and estradiol concentration between the sexes. Testosterone is well known to be anabolic and increases the basal rate of MPS in both healthy and hypogonadal young men $[15,16,41]$. Oddly, however, the effect of testosterone therapy in older men is unclear; it has been shown by the same group, in different studies, to either increase [42] or not to affect [43] the basal rate of MPS. This discrepancy might be a dose- or treatment duration-related phenomenon, or depend upon the extent of initial testosterone deficiency. More importantly, however, we [44] and others [45] measured the basal rate of
MPS in large cohorts of healthy young $(n \geq 22)$ and old $(n \geq 22)$ men and found that it was not affected by old age. This suggests that the normal decline in testosterone with aging, which is small [45], probably has little effect on the basal rate of MPS. On the other hand, there is evidence from studies in rats that progesterone and estrogen inhibit MPS. Specifically, it was found that in ovariectomized rats the rate of MPS was higher than in sham-operated, intact controls and ovariectomy with either progesterone or estrogen replacement prevented the increase [17]. Thus, it appears that the basal rate of MPS probably increases after menopause due to a lack of female sex steroids, which leads to pronounced differences in the basal rate of MPS between men and women not apparent in younger adults. Moreover, these and our findings (i.e., greater basal rate of MPS in women than men despite 10-fold difference in plasma testosterone concentration) suggest that the anti-anabolic effect of female sex steroids on MPS may by far outweigh the anabolic effect of testosterone. 

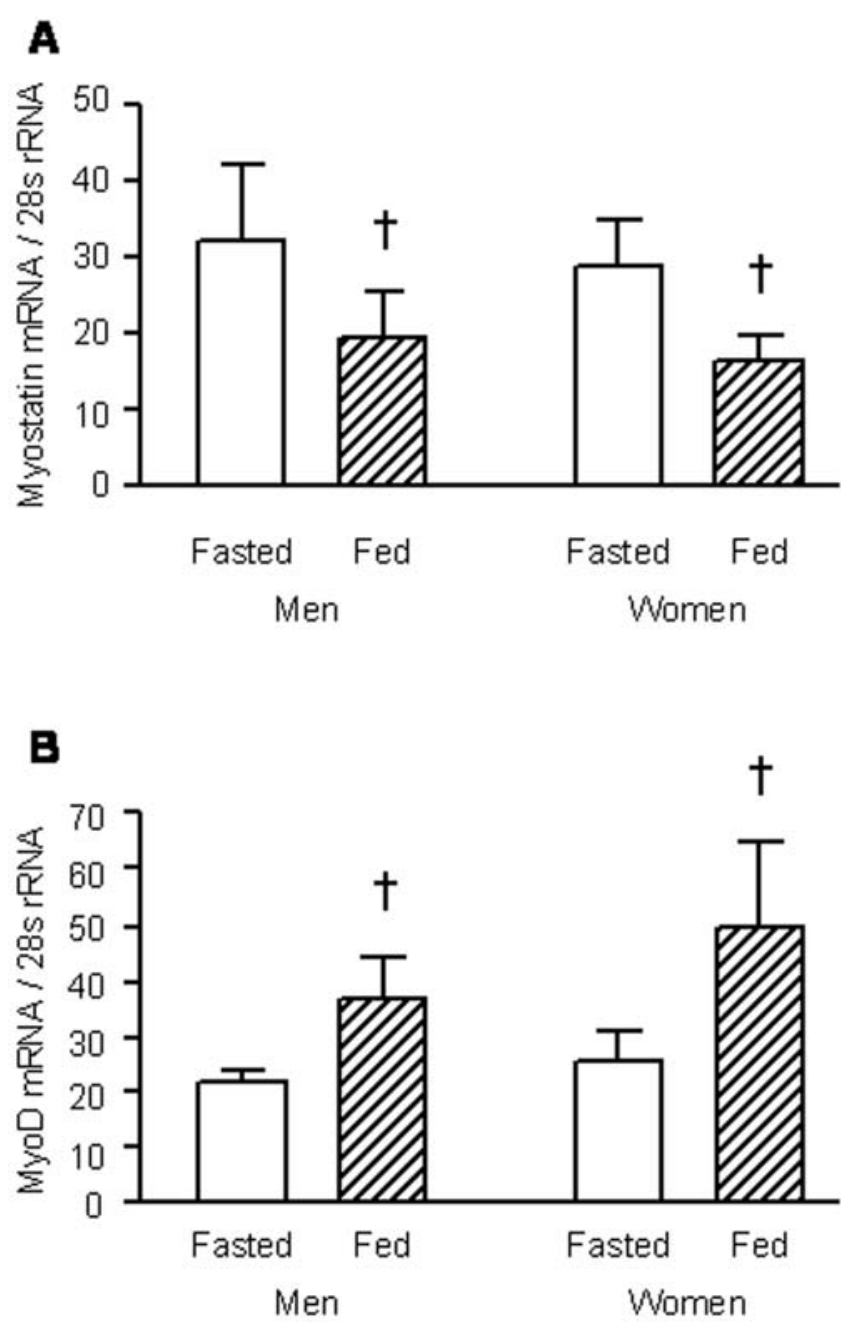

Figure 3. Muscle mRNA expression of proteins involved in the regulation of muscle mass in men and women. Panels $A$ and $B$ show myostatin (A) and myoD (B) gene expression during basal, postabsorptive conditions (fasted) and liquid mixed meal consumption (fed) in men $(n=7)$ and women $(n=7)$. Values are means \pm SEM. ${ }^{\dagger}$ Value significantly different from corresponding value during basal, postabsorptive (fasted) conditions; $P<0.05$.

doi:10.1371/journal.pone.0001875.g003

Another somewhat surprising finding was the fact that the postabsorptive rate of MPS in women was faster despite lower basal plasma leucine concentrations in women than in men. There is ample evidence that the rate of MPS is directly related to plasma amino acid availability [44,46,47], particularly that of plasma leucine [48-51]. However, this relationship has been established when plasma amino acid/leucine concentrations were varied several-fold, whereas the difference in plasma leucine concentration in our men and women was only $\sim 15 \%$, possibly too small to exert a noticeable effect on the rate of MPS as MPS only increases by $50 \%$ with a doubling of leucine concentration [46].

The slightly greater postabsorptive plasma leucine concentration in men, which is in excellent agreement with an earlier report on sex differences in the plasma amino acid profile [52], probably reflects greater net negative protein balance in men than in women but it is difficult to assign components to this, beyond the decreased MPS in men. We did not measure the rate of muscle protein breakdown (MPB) (which was unwarranted without more indicative data of possible sex differences given the already sizeable investigational burden on our subjects). Therefore we are unable to estimate muscle protein net balance. However, whole-body protein breakdown (indicated by leucine $\mathrm{Ra}$ ) was not different between our men and women and as MPB normally accounts for $\sim 20-40 \%$ of a healthy person's postabsorptive whole-body protein breakdown rate $[53,54]$ it is unlikely that MPB was markedly accelerated in men compared with women.

The differences in the anabolic response to feeding between the sexes, with men showing a significant increase and women no significant increase in MPS, was probably partially mediated by a lack of stimulation by feeding of protein translation initiation in female muscle, given that the feeding increased the phosphoryla-

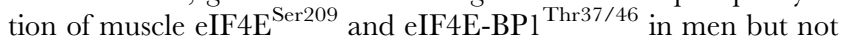
in women. This is particularly interesting given the facts that other indices of anabolic signaling, like the feeding-induced changes in the phosphorylation of $\mathrm{Akt}^{\text {Thr308 }}, \mathrm{p} 70 \mathrm{~s}_{6} \mathrm{k}^{\text {Thr389 }}$, and eEF2 ${ }^{\text {Thr56 }}$ were similar in men and women. An intriguing new finding was the marked (and so far as we can tell previously unreported) changes in the expression of myostatin and myoD with feeding, which are consistent with an acute nutritional control at the level of the nucleus of processes regulating muscle mass [55]. Nevertheless, there was no apparent sex difference in these responses, which makes it unlikely that the feeding-induced changes in myostatin and myoD expression contributed to the blunted increase of MPS to feeding in women. The feedinginduced increases in plasma glucose, insulin, and leucine concentrations were not different in men and women, which suggests that these also were not involved in the apparent anabolic resistance in women. It is possible, however, that there were sex differences in the insulin-stimulated increase in muscle nutritive blood flow which would differentially affect amino acid delivery to the muscle. Although in young adults, the insulin mediated vasodilation is greater in women than in men [56], there is evidence for a greater decline with aging in women compared with men in endothelium dependent dilation induced pharmacologically or by hypoxia [57-59], which may abolish this difference at a more advanced age or even result in reduced flow in women. However all these observations were for measures of bulk blood flow and no pertinent results exist, to our knowledge, for muscle microvascular perfusion [60]. The impact of the sex hormone milieu on the anabolic effect of feeding in muscle is unknown largely due to a lack of data in the literature. To our knowledge, no one has determined the effect of female sex steroids on the anabolic effects of amino acids or food in muscle; however, neither testosterone [43] nor oxandrolone [61] were found to exert an acute additive effect to the stimulatory effect of amino acids on MPS.

Our findings provide a potential mechanism that may help to explain the slower rate of muscle wasting during aging in women than in men [5,7-9]. There is no data available for diurmal variation in human muscle MPS but we suggest that the basal, postabsorptive rate, which was $\sim 30 \%$ greater in our women than in the men, most likely predominates over most of the day. Our arguments depend upon a number of observations. First, the data available from protein intakes in French [62] and North American $[63,64]$ older adults indicate that individuals between $65-80$ y eat on average approximately 9-14 g protein at breakfast, 38-64 g protein at lunch, 19-33 g protein at dinner and 1.2-1.7 g protein in snacks [62]. Secondly, meal feeding causes an increase of plasma total amino acid concentrations that is proportional to the amount of protein consumed for approximately $3-5 \mathrm{~h}$, after which the change returns to within $25 \%$ of baseline [65-67]. Thirdly, the results of a study of the circadian variations of amino acids during a 24-h long study of the effects of 3 meals and two snacks suggested 
that the period of plasma essential amino acids being raised above the postabsorptive morning value was approximately $7 \mathrm{~h}$ [68]. Fourth, there is evidence that a sustained hyperaminoacidemia does not lead to a sustained increase in MPS, which returns to baseline values within approximately $2-2.5 \mathrm{~h}$ of the initial increase of amino acid availability [69]. Lastly, the relationship between amino acid availability and MPS is saturable both for orally delivered free amino acids [44] and orally delivered protein [70], with excess essential amino acids being oxidized above delivery of approximately $15 \mathrm{~g}$ of protein per meal in young trained individuals [70] and probably even less in older adults [44]. Thus, we suggest that MPS proceeds at a rate corresponding closely to fed values in our study for approximately $6-8 \mathrm{~h}$; for the remainder of the day, MPS would presumably operate at or near postabsorptive values. This then would result in a lower than average rate of MPS over the course of the day than in women. We recognize that a complete description of the mechanisms involved in nutritional regulation of muscle mass in the elderly will depend on information about the meal induced changes in muscle protein breakdown. To date, there is no evidence that the sensitivity of MPS in older men and women to insulin released by feeding is different. Furthermore, in a study of 6 older men and 6 older women (68-70 y), who received two doses of insulin during hyperinsulinaemic, isoaminoacidemic clamps, leucine whole body

\section{References}

1. Horowitz JF, Coppack SW, Klein S (2001) Whole-body and adipose tissue glucose metabolism in response to short-term fasting in lean and obese women. Am J Clin Nutr 73: 517-522.

2. Zierler K (1999) Whole body glucose metabolism. Am J Physiol 276: E409-426.

3. Kraegen EW, Jenkins AB, Storlien LH, Chisholm DJ (1990) Tracer studies of in vivo insulin action and glucose metabolism in individual peripheral tissues. Horm Metab Res Suppl 24: 41-48.

4. Radegran G, Blomstrand E, Saltin B (1999) Peak muscle perfusion and oxygen uptake in humans: importance of precise estimates of muscle mass. J Appl Physiol 87: 2375-2380.

5. Forbes GB, Reina JC (1970) Adult lean body mass declines with age: some longitudinal observations. Metabolism 19: 653-663.

6. Mingrone G, Marino S, DeGaetano A, Capristo E, Heymsfield SB, et al. (2001) Different limit to the body's ability of increasing fat-free mass. Metabolism 50: 1004-1007.

7. Gallagher D, Ruts E, Visser M, Heshka S, Baumgartner RN, et al. (2000) Weight stability masks sarcopenia in elderly men and women. Am J Physiol Endocrinol Metab 279: E366-375.

8. Hughes VA, Frontera WR, Roubenoff R, Evans WJ, Singh MA (2002) Longitudinal changes in body composition in older men and women: role of body weight change and physical activity. Am J Clin Nutr 76: 473-481.

9. Zamboni M, Zoico E, Scartezzini T, Mazzali G, Tosoni P, et al. (2003) Body composition changes in stable-weight elderly subjects: the effect of sex. Aging Clin Exp Res 15: 321-327.

10. Bhasin S, Woodhouse L, Storer TW (2001) Proof of the effect of testosterone on skeletal muscle. J Endocrinol 170: 27-38.

11. Buresova M, Gutmann E (1971) Effect of testosterone on protein synthesis and contractility of the levator ani muscle of the rat. J Endocrinol 50: 643-651.

12. Grigsby JS, Bergen WG, Merkel RA (1976) The effect of testosterone on skeletal muscle development and protein synthesis in rabbits. Growth 40: 303-316.

13. Rooyackers OE, Nair KS (1997) Hormonal regulation of human muscle protein metabolism. Annu Rev Nutr 17: 457-485.

14. Umpleby AM, Russell-Jones DL (1996) The hormonal control of protein metabolism. Baillieres Clin Endocrinol Metab 10: 551-570.

15. Ferrando AA, Tipton KD, Doyle D, Phillips SM, Cortiella J, et al. (1998) Testosterone injection stimulates net protein synthesis but not tissue amino acid transport. Am J Physiol 275: E864-871.

16. Griggs RC, Kingston W, Jozefowicz RF, Herr BE, Forbes G, et al. (1989) Effect of testosterone on muscle mass and muscle protein synthesis. J Appl Physiol 66: 498-503.

17. Toth MJ, Poehlman ET, Matthews DE, Tchernof A, MacCoss MJ (2001) Effects of estradiol and progesterone on body composition, protein synthesis, and lipoprotein lipase in rats. Am J Physiol Endocrinol Metab 280: E496-501.

18. McCormick KM, Burns KL, Piccone CM, Gosselin LE, Brazeau GA (2004) Effects of ovariectomy and estrogen on skeletal muscle function in growing rats. J Muscle Res Cell Motil 25: 21-27.

19. Piccone CM, Brazeau GA, McCormick KM (2005) Effect of oestrogen on myofibre size and myosin expression in growing rats. Exp Physiol 90: 87-93.
$\mathrm{Ra}$ (an index of whole-body proteolysis) was not different between the sexes [71]. Additional support comes from a study of $30 \mathrm{y}$ old men and women, in which it was observed that the inhibitory effect of insulin on whole-body proteolysis (assessed during a hyperinsulinemic, euglycemic, isoaminoacidemic clamp) was not different between the sexes but, consonant with our results, in women there appeared to be an anabolic resistance to the stimulatory effect of insulin on whole-body protein synthesis [72].

In summary, we have demonstrated that there is significant sexual dimorphism in MPS and its control in older adults; a greater basal rate of MPS, operating over a large portion of the diurnal cycle, may be, at least in part, responsible for the slower loss of muscle in women than in men.

\section{Acknowledgments}

The authors wish to thank Nicole Wright for subject recruitment and technical assistance, and the study subjects for their participation.

\section{Author Contributions}

Conceived and designed the experiments: BM DV MR. Performed the experiments: GS DV. Analyzed the data: BM GS PA DV TF DR MR. Contributed reagents/materials/analysis tools: BM GS PA DV MR. Wrote the paper: BM GS PA DV MR.
20. Fujita S, Rasmussen BB, Bell JA, Cadenas JG, Volpi E (2007) Basal muscle intracellular amino acid kinetics in women and men. Am J Physiol Endocrinol Metab 292: E77-83

21. Parise G, Mihic S, MacLennan D, Yarasheski KE, Tarnopolsky MA (2001) Effects of acute creatine monohydrate supplementation on leucine kinetics and mixed-muscle protein synthesis. J Appl Physiol 91: 1041-1047.

22. Jahn LA, Barrett EJ, Genco ML, Wei L, Spraggins TA, et al. (1999) Tissue composition affects measures of postabsorptive human skeletal muscle metabolism: comparison across genders. J Clin Endocrinol Metab 84: $1007-1010$.

23. Vary TC, Jefferson LS, Kimball SR (1999) Amino acid-induced stimulation of translation initiation in rat skeletal muscle. Am J Physiol 277: E1077-1086.

24. Millward DJ, Garlick PJ, James WP, Nnanyelugo DO, Ryatt JS (1973 Relationship between protein synthesis and RNA content in skeletal muscle. Nature 241: 204-205.

25. Proud CG (2007) Signalling to translation: how signal transduction pathways control the protein synthetic machinery. Biochem J 403: 217-234.

26. Frost RA, Lang CH (2007) Protein kinase B/Akt: a nexus of growth factor and cytokine signaling in determining muscle mass. J Appl Physiol 103: 378-387.

27. Lee SJ, McPherron AC (2001) Regulation of myostatin activity and muscle growth. Proc Natl Acad Sci U S A 98: 9306-9311.

28. McPherron AC, Lee SJ (2002) Suppression of body fat accumulation in myostatin-deficient mice. J Clin Invest 109: 595-601.

29. Guttridge DC (2004) Signaling pathways weigh in on decisions to make or break skeletal muscle. Curr Opin Clin Nutr Metab Care 7: 443-450.

30. Toth MJ, Matthews DE, Tracy RP, Previs MJ (2005) Age-related differences in skeletal muscle protein synthesis: relation to markers of immune activation. Am J Physiol Endocrinol Metab 288: E883-891.

31. Schaap LA, Pluijm SM, Deeg DJ, Visser M (2006) Inflammatory markers and loss of muscle mass (sarcopenia) and strength. Am J Med 119: 526 e529-517.

32. Visser M, Pahor M, Taaffe DR, Goodpaster BH, Simonsick EM, et al. (2002) Relationship of interleukin-6 and tumor necrosis factor-alpha with muscle mass and muscle strength in elderly men and women: the Health ABC Study. J Gerontol A Biol Sci Med Sci 57: M326-332.

33. Roubenoff R (2003) Catabolism of aging: is it an inflammatory process? Curr Opin Clin Nutr Metab Care 6: 295-299.

34. Dietrichson P, Coakley J, Smith PE, Griffiths RD, Helliwell TR, et al. (1987) Conchotome and needle percutaneous biopsy of skeletal muscle. J Neurol Neurosurg Psychiatry 50: 1461-1467.

35. Patterson BW, Zhang XJ, Chen Y, Klein S, Wolfe RR (1997) Measurement of very low stable isotope enrichments by gas chromatography/mass spectrometry: application to measurement of muscle protein synthesis. Metabolism 46: 943-948.

36. Livak KJ, Schmittgen TD (2001) Analysis of relative gene expression data using real-time quantitative PCR and the 2(-Delta Delta C(T)) Method. Methods 25: 402-408.

37. Watt PW, Lindsay Y, Scrimgeour CM, Chien PA, Gibson JN, et al. (1991) Isolation of aminoacyl-tRNA and its labeling with stable-isotope tracers: Use in 
studies of human tissue protein synthesis. Proc Natl Acad Sci U S A 88: 5892-5896.

38. Mittendorfer B, Andersen JL, Plomgaard P, Saltin B, Babraj JA, et al. (2005) Protein synthesis rates in human muscles: neither anatomical location nor fibretype composition are major determinants. J Physiol 563: 203-211.

39. Welle S, Tawil R, Thornton CA (2008) Sex-related differences in gene expression in human skeletal muscle. PLoS ONE 3: e1385.

40. McMahon CD, Popovic L, Jeanplong F, Oldham JM, Kirk SP, et al. (2003) Sexual dimorphism is associated with decreased expression of processed myostatin in males. Am J Physiol Endocrinol Metab 284: E377-381.

41. Brodsky IG, Balagopal P, Nair KS (1996) Effects of testosterone replacement on muscle mass and muscle protein synthesis in hypogonadal men-a clinical research center study. J Clin Endocrinol Metab 81: 3469-3475.

42. Urban RJ, Bodenburg YH, Gilkison C, Foxworth J, Coggan AR, et al. (1995) Testosterone administration to elderly men increases skeletal muscle strength and protein synthesis. Am J Physiol 269: E820-826.

43. Ferrando AA, Sheffield-Moore M, Paddon-Jones D, Wolfe RR, Urban RJ (2003) Differential anabolic effects of testosterone and amino acid feeding in older men. J Clin Endocrinol Metab 88: 358-362.

44. Cuthbertson D, Smith K, Babraj J, Leese G, Waddell T, et al. (2005) Anabolic signaling deficits underlie amino acid resistance of wasting, aging muscle. Faseb J 19: 422-424.

45. Volpi E, Sheffield-Moore M, Rasmussen BB, Wolfe RR (2001) Basal muscle amino acid kinetics and protein synthesis in healthy young and older men. JAMA 286: 1206-1212.

46. Bohe J, Low A, Wolfe RR, Rennie MJ (2003) Human muscle protein synthesis is modulated by extracellular, not intramuscular amino acid availability: a doseresponse study. J Physiol 552: 315-324.

47. Kobayashi H, Borsheim E, Anthony TG, Traber DL, Badalamenti J, et al. (2003) Reduced amino acid availability inhibits muscle protein synthesis and decreases activity of initiation factor eIF2B. Am J Physiol Endocrinol Metab 284: E488-498.

48. Rennie MJ, Bohe J, Smith K, Wackerhage H, Greenhaff P (2006) Branchedchain amino acids as fuels and anabolic signals in human muscle. J Nutr 136: 264S-268S.

49. Crozier SJ, Kimball SR, Emmert SW, Anthony JC, Jefferson LS (2005) Oral leucine administration stimulates protein synthesis in rat skeletal muscle. J Nutr 135: $376-382$.

50. Garlick PJ (2005) The role of leucine in the regulation of protein metabolism. J Nutr 135: 1553S-1556S.

51. Rieu I, Balage M, Sornet C, Giraudet C, Pujos E, et al. (2006) Leucine supplementation improves muscle protein synthesis in elderly men independently of hyperaminoacidaemia. J Physiol 575: 305-315.

52. Pitkanen HT, Oja SS, Kemppainen K, Seppa JM, Mero AA (2003) Serum amino acid concentrations in aging men and women. Amino Acids 24: 413-421.

53. Long CL, Birkhahn RH, Geiger JW, Blakemore WS (1981) Contribution of skeletal muscle protein in elevated rates of whole body protein catabolism in trauma patients. Am J Clin Nutr 34: 1087-1093.

54. Morais JA, Gougeon R, Pencharz PB, Jones PJ, Ross R, et al. (1997) Wholebody protein turnover in the healthy elderly. Am J Clin Nutr 66: 880-889.

55. Partridge T (2000) The current status of myoblast transfer. Neurol Sci 21: S939-942.
56. Lind L, Fugmann A, Millgard J, Berne C, Lithell H (2002) Insulin-mediated vasodilatation, but not glucose uptake or endothelium-mediated vasodilatation, is enhanced in young females compared with males. Clin Sci (Lond) 102: 241-246.

57. Celermajer DS, Sorensen KE, Spiegelhalter DJ, Georgakopoulos D, Robinson, et al. (1994) Aging is associated with endothelial dysfunction in healthy men years before the age-related decline in women. J Am Coll Cardiol 24: $471-476$.

58. Sarabi M, Millgard J, Lind L (1999) Effects of age, gender and metabolic factors on endothelium-dependent vasodilation: a population-based study. J Intern Med 246: $265-274$.

59. Jensen-Urstad K, Johansson J (2001) Gender difference in age-related changes in vascular function. J Intern Med 250: 29-36.

60. Clark MG, Rattigan S, Barrett EJ (2006) Nutritive blood flow as an essential element supporting muscle anabolism. Curr Opin Clin Nutr Metab Care 9: 185-189.

61. Sheffield-Moore M, Urban RJ, Wolf SE, Jiang J, Catlin DH, et al. (1999) Shortterm oxandrolone administration stimulates net muscle protein synthesis in young men. J Clin Endocrinol Metab 84: 2705-2711.

62. Rousset S, Patureau Mirand P, Brandolini M, Martin JF, Boirie Y (2003) Daily protein intakes and eating patterns in young and elderly French. Br J Nutr 90: $1107-1115$.

63. Cid-Ruzafa J, Caulfield LE, Barron Y, West SK (1999) Nutrient intakes and adequacy among an older population on the eastern shore of Maryland: the Salisbury Eye Evaluation. J Am Diet Assoc 99: 564-571.

64. Ledikwe JH, Smiciklas-Wright H, Mitchell DC, Miller CK, Jensen GL (2004) Dietary patterns of rural older adults are associated with weight and nutritional status. J Am Geriatr Soc 52: 589-595.

65. Adibi SA, Mercer DW (1973) Protein digestion in human intestine as reflected in luminal, mucosal, and plasma amino acid concentrations after meals. J Clin Invest 52: 1586-1594.

66. Bergstrom J, Furst P, Vinnars E (1990) Effect of a test meal, without and with protein, on muscle and plasma free amino acids. Clin Sci (Lond) 79: 331-337.

67. Remond D, Machebeuf M, Yven C, Buffiere C, Mioche L, et al. (2007) Postprandial whole-body protein metabolism after a meat meal is influenced by chewing efficiency in elderly subjects. Am J Clin Nutr 85: 1286-1292.

68. Tsai PJ, Wu WH, Huang PC (2000) Circadian variations in plasma neutral and basic amino acid concentrations in young men on an ordinary Taiwanese diet. J Formos Med Assoc 99: 151-157.

69. Bohe J, Low JF, Wolfe RR, Rennie MJ (2001) Latency and duration of stimulation of human muscle protein synthesis during continuous infusion of amino acids. J Physiol 532: 575-579.

70. Moore D, Phillips S (2008) Dose response relationship between protein ingestion and muscle protein synthesis post exercise in young men. In Experimental Biology 2008. San Diego, CA.

71. Boirie Y, Gachon P, Cordat N, Ritz P, Beaufrere B (2001) Differential insulin sensitivities of glucose, amino acid, and albumin metabolism in elderly men and women. J Clin Endocrinol Metab 86: 638-644.

72. Chevalier S, Marliss EB, Morais JA, Lamarche M, Gougeon R (2005) The influence of sex on the protein anabolic response to insulin. Metabolism 54: $1529-1535$. 